\title{
INDICADORES DE DESENVOLVIMENTO PROFISSIONAL DA DOCÊNCIA: CONSTRUÇÃO, AVALIAÇÃO E USOS
}

PAULO HENRIQUE LEAL ALINE MARIA DE MEDEIROS RODRIGUES REALI

\section{RESUMO}

Neste artigo, abordam-se algumas ideias relativas à construção de indicadores educacionais referentes ao desenvolvimento profissional docente, à avaliação da composição da base de conhecimento para o ensino e para o exercício profissional da docência e sua utilidade para a definição de políticas públicas de formação de professores. Apresentam-se e discutem-se alguns dados obtidos numa investigação que teve como propósito geral caracterizar níveis de proficiência para o ensino de um professor de Educação Física experiente, considerando que a construção e o desenvolvimento da carreira docente apresentam estágios diversificados e envolvem diferentes processos de aprendizagem profissional. Os dados obtidos podem ser compreendidos como um conjunto de indicadores de desenvolvimento profissional da docência, já que se relacionam aos conhecimentos necessários para o ensino e para o exercício profissional da docência, tendo em vista o local de atuação e aspectos da trajetória profissional do professor investigado.

PALAVRAS-CHAVE DESENVOLVIMENTO PROFISSIONAL • FORMAÇÃO DE PROFESSORES • FORMAÇÃO PROFISSIONAL • EDUCAÇÃO FÍSICA. 


\section{RESUMEN}

En este artículo se abordan algunas ideas relativas a la construcción de indicadores educativos referentes al desarrollo profesional docente, a la evaluación de la composición de la base de conocimiento para la enseñanza y el ejercicio profesional de la docencia y su utilidad para definir políticas públicas de formación de profesores. Se presentan y discuten algunos datos obtenidos en una investigación cuyo propósito general fue el de caracterizar niveles de proficiencia para la enseñanza de un profesor de Educación Física experimentado, considerando que la construcción y el desarrollo de la carrera docente presentan estadios diversificados e implican distintos procesos de aprendizaje profesional. Los datos obtenidos se pueden comprender como un conjunto de indicadores de desarrollo profesional de la docencia, ya que se relacionan con los conocimientos necesarios para enseñar y ejercer profesionalmente la docencia, teniendo en cuenta el sitio de actuación y aspectos de la trayectoria profesional del profesor investigado.

PALABRAS CLAVE DESARROLLO PROFESIONAL・FORMACIÓN DE PROFESORES - FORMACIÓN PROFESIONAL • EDUCACIÓN FÍSICA.

\section{ABSTRACT}

This article presents some ideas concerning the construction of educational indicators related to teacher professional development, evaluation of the composition of the knowledge base for teaching and for teaching professional practice and their role in the definition of public policies for teacher training. Data obtained in an investigation aimed at characterizing the levels of proficiency in teaching of an experienced Physical Education teacher are presented and discussed, considering that the construction and development of the teaching career is characterized by diverse stages and involve different processes of professional learning. The data obtained can be understood as a set of professional teaching development indicators, since they relate to the knowledge needed for teaching and for the professional teaching career, in view of the place and aspects of the professional career of the teacher investigated.

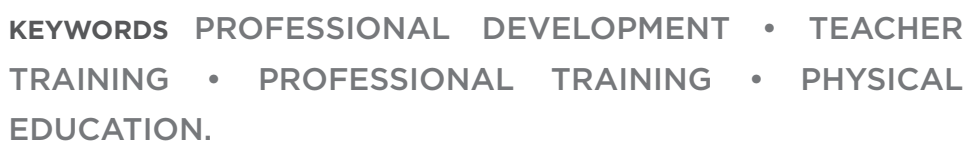


1 A Lei n. 11.274 (BRASIL, 2006) alterou a duração do ensino fundamental de oito para nove anos,

transformando o último ano da educação infantil no primeiro ano do ensino fundamental. A despeito dessa mudança, manteve-se o termo "séries" porque a escola considerada neste estudo utilizava essa denominação na época da coleta dos dados.

\section{INTRODUÇÃO}

Neste artigo, são analisados os resultados referentes à caracterização da base de conhecimento para o ensino e para o exercício profissional da docência, considerando as $3^{\mathrm{a}}$ e $4^{\mathrm{a}}$ séries ${ }^{1}$ do ensino fundamental, apresentada por um professor de Educação Física experiente. A finalidade deste estudo é identificar indicadores de desenvolvimento profissional da docência, considerando a área, as séries de ensino e os anos de atuação. Em vista de tais objetivos, abordam-se algumas ideias relativas à construção de indicadores educacionais referentes ao desenvolvimento profissional docente, à avaliação da base de conhecimento para o ensino e sua utilidade para a definição de ações e políticas públicas de formação de professores. Mais especificamente, apresentam-se e discutem-se alguns dados obtidos numa investigação que teve como propósito geral caracterizar níveis de proficiência para o ensino e para o exercício profissional da docência de um professor de Educação Física experiente. Para tanto, considerou-se que a construção e o desenvolvimento da carreira docente apresentam estágios diversificados, 
envolvem conhecimentos para o ensino específicos derivados de processos diversificados de aprendizagem profissional. Os dados obtidos podem ser compreendidos como um conjunto de indicadores de desenvolvimento profissional da docência, já que se relacionam aos conhecimentos necessários para o ensino e para o exercício profissional tendo em vista o local de atuação e aspectos da trajetória profissional do professor investigado.

\section{A CONSTRUÇÃO DE INDICADORES EDUCACIONAIS POR PROFESSORES: A POSSIBILIDADE DE MAPEAR A BASE DE CONHECIMENTO PARA O ENSINO2 TENDO EM VISTA AS DIFERENTES FASES DA CARREIRA ${ }^{3}$}

Os indicadores educacionais podem ser compostos de informações de diferentes naturezas ou estatísticas, colhidas ou determinadas com base em várias fontes e que refletem aspectos importantes de um sistema educacional, de uma rede de ensino ou até mesmo de uma escola e dos processos a essas instâncias relacionados. Observa-se que diversas agências responsáveis pelo delineamento de políticas públicas educacionais no Brasil pautam usualmente suas decisões em indicadores de produto referentes aos atores envolvidos (por exemplo: horas trabalhadas, número de alunos por professor) ou a resultados de processos de ensino e aprendizagem, como é o caso dos índices de retenção, aprovação, abandono, notas obtidas em provas aplicadas a um grande contingente da população escolar, ou mesmo custo-aluno.

No caso de professores, dados como os derivados do Censo dos Profissionais do Magistério da Educação Básica (BRASIL, 2003) são de grande utilidade, pois oferecem informações sobre componentes/variáveis como a rede de ensino à qual se vinculam, o número de escolas em que atuam, as atividades de formação continuada de que participam, etc. Tais estatísticas devem possibilitar comparações e oferecer subsídios para a descrição, ainda que aproximada, do que ocorre numa realidade educacional tendo em vista alguns critérios previamente definidos num dado período de tempo. Devem admitir, assim, o monitoramento de certas condições
2 Compreendida como o que os "professores deveriam saber, fazer, compreender ou professar para converter o ensino em algo mais que uma forma de trabalho individual e para que seja considerada entre as profissões prestigiadas", conforme Shulman (2005, p. 5).

3 As ideias apresentadas nesta seção têm como base pesquisas realizadas anteriormente por Reali (2001) e Reali et al. (2005). 
que se alteram ao longo do tempo e em decorrência de variáveis como a introdução de novas políticas educacionais; o ingresso de novos profissionais nas redes de ensino ou mesmo de certas características de coortes de alunos atendidos. Podem variar no seu escopo: podem ser amplas e abranger um sistema de ensino ou mais limitadas e se referir a uma escola em particular (REALI, 2011).

Nota-se com frequência, porém, o uso "instrumental" de indicadores educacionais, pois se supõe que per se possibilitam a construção de políticas públicas mais racionais e adequadas. Nessa perspectiva, os indicadores são percebidos como representações das relações entre vários componentes, oferecendo informações sobre aspectos considerados críticos e pautam-se em um modelo conceitual predefinido da situação ou do processo analisado. Para cada um dos componentes considerados, são construídos indicadores que possibilitam a análise das relações existentes entre eles. No geral, essas relações são percebidas como causais (quanto maiores os investimentos financeiros realizados na formação docente, maior a qualidade do ensino, por exemplo) e os processos educacionais são compreendidos, medidos e representados por meio de dados numéricos.

Contudo, sem desconsiderar o valor dessas iniciativas, defende-se aqui uma visão alternativa, na qual, por meio do estabelecimento de quadros de referências, podem ser elaborados indicadores educacionais por professores, incluindo os relativos ao desenvolvimento profissional da docência. Nessa ótica, elementos-chave do processo de desenvolvimento profissional da docência podem ser apreendidos sem aterem-se a um determinado modelo predefinido de atuação e mesmo de formação. A definição de um quadro de referências nesse formato não implica o estabelecimento de relações causais entre os vários componentes, não favorece o uso instrumental dos resultados obtidos e tampouco oferece a prescrição de um "remédio". Pode, entretanto, oferecer informações para fomentar e orientar a discussão sobre aspectos relevantes de um sistema educacional como atuação docente e características instrucionais da escola, como a qualidade do currículo e dos objetivos escolares, e o que é 
realizado ou necessário para promover o profissionalismo docente.

Não se pode desconsiderar, de acordo com Lustick e Sykes (2006), que os professores detêm conhecimentos especializados que podem ser identificados, sistematizados, aperfeiçoados e até ensinados a outros docentes. Esses conhecimentos são indicados em inúmeros contextos e podem ser observados em currículos de formação inicial e continuada e em parâmetros de desenvolvimento profissional. Podem ainda ser utilizados para acompanhar processos de formação e desenvolvimento profissional da docência.

Defende-se também, a despeito da diversidade teórico-metodológica sobre o que constitui um indicador educacional, que é mais importante manter a sua definição em aberto e centrar o foco em suas potencialidades, para que estão sendo definidos e quais questões pretendem (e/ou podem) responder em função de um determinado contexto.

Um sistema de indicadores educacionais, em geral, possibilita não só o monitoramento de certas circunstâncias como também do desenvolvimento, do progresso ou até a comparação de processos (SHAVELSON; BAXTER; PINE, 1991), como é o caso do desenvolvimento profissional da docência. Pode ainda demonstrar a accountability de sistemas educacionais; favorecer análises de políticas ou mesmo subsidiar a sua formulação (NUTTALL, 1994). Ao considerar a escola e a sala de aula, os indicadores educacionais devem informar e oferecer dados que possibilitem a reflexão dos participantes da comunidade escolar sobre atividades que realizam, assim como também devem ajudá-los a construir compreensões mais detalhadas e profundas sobre os processos educacionais promovidos (BRYK; HERMANSON, 1993).

Assume-se, portanto, que os indicadores podem auxiliar a elaboração de ações contextualizadas quando as informações a eles relacionadas forem analisadas à luz da cultura e dos valores da comunidade escolar e, ainda, quando esta se torne responsável pelos seus atos e seja responsiva às necessidades a ela impostas (DARLING-HAMMOND; ASCHER, 1991).

Os indicadores de processos próprios de uma categoria profissional - como os que aqui se propõem - oferecem elementos, 
ou parâmetros de referência, sobre as atividades desenvolvidas, os conceitos e valores adotados sobre os alunos, a aprendizagem, o ensino, as práticas pedagógicas, a organização curricular, as políticas acadêmicas, entre outros. Proporcionam elementos para a construção e o desenvolvimento de ações formativas específicas e a definição de como podem ser promovidas, considerando a cultura própria de cada contexto escolar em que os docentes atuam e as suas características (BRYK; HERMANSON, 1993). Possibilitam orientar projetos para promover e monitorar o progresso nas diferentes fases da carreira docente (SANDERS; KEARNEY, 2008) e trajetórias de desenvolvimento profissional. Para tanto, é relevante obter informações sobre os níveis de proficiência dos professores e as possibilidades para o acesso e a extensão das oportunidades para a promoção da aprendizagem da docência; os incentivos, as exigências e as condições para que esta ocorra, bem como outros aspectos que podem facilitar ou limitar ações em benefício do seu desenvolvimento profissional. Um conjunto de indicadores sobre o desenvolvimento docente pode oferecer subsídios para a formulação e a definição de objetivos educacionais, de padrões de desempenho desejáveis de professores e seus estudantes e como estes podem ser construídos e adotados por uma determinada comunidade escolar. Permitem, em particular, apontar aspectos relevantes para a definição de processos e de conteúdos a serem tratados na formação inicial e continuada de professores.

Contudo, concebe-se que a mera definição de parâmetros de referência não implica a alteração das práticas pedagógicas de professores ou a aprendizagem dos alunos. A articulação dos sistemas educacionais, a autonomia, a capacidade organizacional e colaborativa da escola, a existência de recursos técnicos e financeiros, aliadas às políticas voltadas para as demandas identificadas são fatores essenciais para que esses objetivos sejam atingidos.

Para construir indicadores, segundo esse formato, é importante que professores de um sistema educacional ou de uma escola tenham possibilidade de analisar coletivamente os conteúdos específicos a serem aprendidos pelos alunos para, em seguida, examinarem quais conhecimentos necessitam saber 
para ensiná-los. E nessa tarefa é relevante definir, além do que deve ser aprendido (o conteúdo), o quanto (em que grau de proficiência), o como (de que maneira) e por que os alunos devem aprender. Esses mesmos procedimentos podem ser aplicados aos professores.

O levantamento dos aspectos apontados pode compor o passo inicial de uma descrição detalhada do que ocorre numa dada realidade educacional, tendo em vista alguns critérios previamente definidos e considerando certo período de tempo. Pode ainda influenciar o modo como os professores pensam e agem, particularmente quando se consideram as decisões tomadas no âmbito da sala de aula e nos processos de ensino, pois oferecem subsídios para o estabelecimento de novas visões e expectativas sobre os alunos e a sua aprendizagem (BOTTANI; TUIJNMAN, 1994). Pode também direcionar o que é e como é ensinado e a sua sistematização pode resultar em quadros referenciais do currículo que se articulam estreitamente ao que os professores devem conhecer para ensinarem e para serem profissionais numa organização escolar e em um sistema de ensino, tendo em vista os processos pessoais de desenvolvimento profissional, as experiências profissionais, os anos de prática docente e os contextos em que atuam, isto é, os indicadores de desenvolvimento profissional da docência.

Tais indicadores podem funcionar como uma das "alavancas políticas mais importantes pois capturam aspectos importantes do ensino" (DARLING-HAMMOND, 1997, p. 313). Em países como Estados Unidos, Inglaterra e Austrália, as iniciativas voltadas para a definição de indicadores têm sido realizadas por associações docentes, consórcios, etc., e são essenciais para a composição de uma "base de conhecimento compartilhada” (DARLING-HAMMOND, 1997, p. 314, grifo nosso), a partir da consideração do ensino como uma atividade situada, uma vez que as suas características se relacionam com aquelas dos alunos e do espaço e tempo em que ocorrem. Nesses casos, o ensino é concebido como uma atividade complexa, contingente e recíproca, ou seja, que é modelada e remodelada em função das respostas dos estudantes às experiências desenvolvidas em sala de aula. Ao relacionar a 
4 Disponivel em: <www.nswteachers. nsw.edu.au>. Acesso em: 15 maio 2010 base de conhecimento dos alunos com a de seus professores, é possível levar em conta a diversidade e a singularidade de ambos.

No Quadro 1, segue um exemplo referente aos indicadores de desenvolvimento profissional docente estabelecidos na Austrália em 2006-2007. Esses parâmetros de referência, ou indicadores de processo, foram desenvolvidos pelo New South Wales Institute of Teachers (NEW SOUTH WALES, 2010 $)^{4}$ em parceria com professores do país como um todo; foram construídos e validados em estudo conduzido pela Universidade da Nova Inglaterra, que envolveu 7.000 professores. Os indicadores definidos se organizam com base em quatro estágios da carreira docente: professores iniciantes (graduados); professores que ultrapassaram a fase de indução (competentes); professores competentes e comprometidos (completos) e professores socialmente reconhecidos como comprometidos com a promoção de um ensino de qualidade (líderes); três domínios (conhecimento profissional; prática profissional e compromisso profissional) e sete elementos (os professores conhecem a matéria/conteúdo e o modo de ensiná-lo tendo em vista os seus alunos; os professores conhecem os alunos e como aprendem; os professores planejam, avaliam e registram o processo de ensino; os professores constroem e mantêm ambientes de aprendizagem seguros por meio do uso de estratégias de manejo adequadas; os professores continuamente se engajam como membros da sua comunidade profissional e comunidade em geral). 
QUADRO 1 - Exemplos de indicadores de desenvolvimento profissional docente

\begin{tabular}{|c|c|c|c|c|}
\hline \multirow{2}{*}{ ASPECTO } & \multicolumn{4}{|c|}{ ESTÁGIO } \\
\hline & GRADUADO & COMPETENTE & COMPLETO & LÍDER \\
\hline $\begin{array}{l}\text { Conhecimento } \\
\text { do conteúdo } \\
\text { específico }\end{array}$ & $\begin{array}{l}1.1 .1 \text { Possui conhecimento } \\
\text { relevante dos conceitos } \\
\text { centrais, modos de inquirição } \\
\text { e estrutura do conteúdo/ } \\
\text { disciplina. }\end{array}$ & $\begin{array}{l}\text { 1.2.1 Aplica e utiliza } \\
\text { o conhecimento } \\
\text { do conteúdo/ } \\
\text { disciplina por meio } \\
\text { de atividades de } \\
\text { ensino e programas } \\
\text { efetivos vinculados } \\
\text { estritamente } \\
\text { aos conteúdos e } \\
\text { estágios. }\end{array}$ & $\begin{array}{l}\text { 1.3.1 Demonstra e } \\
\text { compartilha com outros } \\
\text { professores conhecimentos } \\
\text { dos conteúdos/disciplinas } \\
\text { visando a desenvolver } \\
\text { atividades de ensino e } \\
\text { programa efetivo. }\end{array}$ & $\begin{array}{l}1.4 .1 \text { Inicia ou lidera o } \\
\text { desenvolvimento de } \\
\text { políticas, programas } \\
\text { e processos que } \\
\text { promovem o avanço } \\
\text { da aprendizagem dos } \\
\text { alunos por meio do } \\
\text { uso de estratégias de } \\
\text { ensino que promovam } \\
\text { conhecimentos de alto } \\
\text { nível do conteúdo/ } \\
\text { disciplina ensinada. }\end{array}$ \\
\hline
\end{tabular}

Fonte: Excerto adaptado do Professional Teaching Standards da NSW Institute of Teachers de 2010.

\section{A APRENDIZAGEM DA DOCÊNCIA E A BASE DE CONHECIMENTO PARA O ENSINO: APONTAMENTOS DE UMA PROBLEMÁTICA TENDO EM VISTA PROFESSORES EM DIFERENTES FASES DA CARREIRA DOCENTE E A EDUCAÇÃO FÍSICA}

$\mathrm{O}$ ensino tem sido reconhecido como uma atividade complexa, já que exige do professor a combinação e o estabelecimento de diferentes tipos de conhecimento: do conteúdo específico e pedagógico, das habilidades para ensinar alunos diversos, além da compreensão do contexto no qual atua, o que contraria a ideia de que qualquer um pode ensinar. Trata-se, portanto, de um tipo de atividade que requisita preparo específico para a sua realização.

Os processos de aprendizagem docente relacionam-se a diferentes fases da carreira, tais como as que antecedem a formação inicial, os primeiros anos de inserção profissional, o desenvolvimento profissional posterior na escola. A aprendizagem docente é um processo contínuo que ocorre ao longo da trajetória dos professores e que não se limita aos espaços formais e tradicionais de formação, tais como os cursos de formação inicial, já que também se pode aprender com outros professores e ensinando. Aprendem ainda por meio de processos de observação vivenciados ao longo das suas vidas como estudantes. Numerosos estudos apontam que, em função desses períodos, os profissionais docentes 
vivenciam sentimentos, dilemas e problemas específicos. Nesse sentido, entende-se que as demandas formativas dos professores se alteram de acordo com a fase da carreira em que se encontram e segundo as características dos contextos de atuação, como das escolas, das salas de aula e dos alunos.

Por meio de processos distintos, mas muitas vezes inter-relacionados, de aprendizagem da docência, podem-se destacar duas vertentes. Uma relativa à aprendizagem sobre ensinar e que se traduz nas compreensões do professor sobre si próprio, a respeito dos alunos, da matéria, do currículo, das estratégias de ensino e de avaliação visando à aprendizagem dos alunos. Implica, especificamente, transformar o conteúdo a ser ensinado em conteúdo aprendido pelos alunos. Abarca a relação tripla entre professores, alunos e conteúdos. Requer a atuação em situações caracterizadas pela singularidade, incerteza, imprevisibilidade, instabilidade e conflito - em que uma pergunta de um aluno, por exemplo, pode demandar informações variadas e exigir um repertório comportamental profissional que permita agir em "zonas indeterminadas da prática", em que a "solução" de um problema não necessariamente pode ser estendida para outro, conforme destacam Pacheco e Flores (1999), alterando, desse modo, o curso de uma aula.

A outra vertente refere-se a ser um profissional. É mais ampla que a anterior, desde que a atuação docente inclua assumir responsabilidades sociais e políticas na escola e na comunidade, além das ações alusivas ao ensinar, tais como participar do seu grupo profissional; compreender as variáveis objetivas que atuam sobre a atividade docente; requisitar condições adequadas para o exercício profissional, entre outras.

Entende-se, portanto, que o que um docente deve saber para ensinar e ser um profissional não se restringe ao domínio de um conjunto de conteúdos específicos ou especializados. Estudos apontam que a construção de uma base de conhecimentos para exercer tais funções, em cursos de formação inicial, é limitada. Ela se torna mais aprofundada, diversificada e flexível a partir da experiência profissional refletida e objetivada. Na realidade, considerando as diversas fases da 
carreira, essa base se refere ao que um professor de História (Geografia, Biologia, Educação Física, etc.) deve saber de forma a exercer a sua profissão com um repertório mínimo que possibilite, de um lado, atender o que se espera da atividade docente e, de outro, a construir novos conhecimentos.

Como exemplos de iniciativas referentes à definição do que futuros professores devem aprender nos processos formativos, podem ser citados, respectivamente, os Parâmetros Curriculares Nacionais (BRASIL, 1997) e a Proposta de Diretrizes para a Formação Inicial de Professores da Educação Básica em Cursos de Nível Superior (BRASIL, 2000).

Aparentemente, professores em início de carreira e os mais experientes apresentam diferenças na base do conhecimento para o ensino e para ser um profissional, embora seja necessário destacar que mais anos de atividade docente não se relacionam diretamente com mais conhecimento profissional. Ainda que pesquisas venham focalizando os anos iniciais da docência (PAPI; MARTINS, 2010), alguns pesquisadores (DAY; GU, 2009; LEAL, 2007; LEAL; FERREIRA, 2006, 2007a, 2007b, 2008, 2009, 2011) tentam compreender o trabalho de professores experientes, a sua configuração, os desafios e as tensões que afetam suas práticas.

Um aspecto a ser considerado nessa discussão diz respeito à própria definição de professor experiente, uma vez que não há critérios claros para sua identificação e tampouco para definição da extensão de conhecimento requerida para assim ser qualificado. $O$ sentido de experiente numa cultura pode ser diferente em outra. Considerar o desempenho dos estudantes como critério também pode dificultar a sua definição, pois o "bom ensino" pode diferir do "ensino bem-sucedido". Essa falta de clareza resulta, com frequência, em concepções homogêneas sobre grupos de professores com algumas características comuns, como tempo de carreira, e dificultam a compreensão da natureza diferenciada do trabalho em fases distintas das suas carreiras (DAY; GU, 2009).

Todavia, provavelmente, à medida que professores vão se tornando mais experientes, seu modo de enfrentar os desafios, de manter a motivação e de atuar passa a diferir do modo dos iniciantes. Esses aspectos podem ter se alterado 
5 Glaser, R. Thoughts on expertise. In: Schooler, C.; Schaie, K. W. (Ed.) Cognitive functioning and social structure over the life course. Norwood, NJ: Ablex, 1987. p. 81-94 em resposta às suas vivências a partir de reformas sociais e políticas, direções das escolas, coortes de alunos, envelhecimento e circunstâncias pessoais (DAY; GU, 2009). De acordo com Glaser $^{5}$ (1987 apud VILLEGAS-REIMERS, 2003, p. 40-41), os seguintes critérios (Quadro 2) podem caracterizar professores experientes:

QUADRO 2 - Critérios para a definição de professores experientes

\begin{tabular}{|c|c|}
\hline ELEMENTOS & CARACTERÍSTICAS DE PROFESSORES EXPERIENTES \\
\hline Domínio e contextos & $\begin{array}{l}\text { Demonstram excelência na sua área de atuação e em } \\
\text { contextos particulares }\end{array}$ \\
\hline Automatismo & $\begin{array}{l}\text { Aprendem a responder automaticamente a certos } \\
\text { incidentes recorrentes na sua profissão }\end{array}$ \\
\hline $\begin{array}{l}\text { Demandas de tarefas } \\
\text { e situações sociais }\end{array}$ & $\begin{array}{l}\text { São mais sensíveis às demandas das tarefas (tendo em } \\
\text { vista quem são os seus alunos e contextos de origem) } \\
\text { e também aos contextos sociais relacionados às } \\
\text { demandas das tarefas }\end{array}$ \\
\hline $\begin{array}{l}\text { Oportunidades e } \\
\text { flexibilidade }\end{array}$ & $\begin{array}{l}\text { Utilizam as oportunidades de modo mais efetivo e se } \\
\text { mostram mais flexíveis na implementação de estratégias } \\
\text { de ensino e em responder aos seus alunos }\end{array}$ \\
\hline $\begin{array}{l}\text { Abordagem dos } \\
\text { problemas }\end{array}$ & $\begin{array}{l}\text { Abordam os problemas de modo diverso dos iniciantes, } \\
\text { pois parecem compreendê-los/representá-los de forma } \\
\text { distinta }\end{array}$ \\
\hline
\end{tabular}

Fonte: Elaboração dos autores com base em Villega-Reimers (2003).

Para Berliner (2001), professores experientes apresentam, além das características indicadas, padrões de reconhecimento mais rápidos e mais acurados sobre a sua área de domínio; respostas mais lentas aos problemas, mas com utilização de fontes de informação mais ricas e mais pessoais para lidar com as dificuldades. Parecem pautar as suas ações apoiando-se em estruturas diferentes e mais complexas que os iniciantes, uma vez que apresentam a capacidade de exercer um controle voluntário e estratégico sobre os processos de ensino e aprendizagem, que ocorre de modo mais automatizado no caso dos iniciantes (PACHECO; FLORES, 1999). A experiência favorece a construção de um conhecimento situado, desenvolvido em função dos contextos de atuação, que, ao ser mobilizado, tende a lançar mão das características do ambiente como ferramentas de solução para as dificuldades enfrentadas.

Os experientes possivelmente detêm quantidade maior e mais flexível de conhecimentos, o que favorece a composi- 
ção de um quadro de referências mais amplo para lidar com as demandas do ensino e da docência. Mostram-se mais responsivos às demandas dos ambientes e são capazes de alterar o rumo das suas ações em resposta às necessidades dos alunos e às variáveis do contexto. Por isso, são capazes de desenvolver oportunidades de aprendizagem mais efetivas com grupos de alunos específicos. Detêm um tipo de estoque de informações que são usadas como "lentes" para interpretar os eventos, construindo, portanto, representações mais complexas sobre o ensino.

Os professores apresentam, dessa maneira, uma base de conhecimento para o ensino (SHULMAN, 2005) e para atuarem profissionalmente que pode variar em função da sua experiência e que consiste em um corpo de compreensões, conhecimentos, habilidades e disposições necessários para propiciar processos de ensinar e de aprender. Essa base envolve conhecimentos de diferentes naturezas, todos indispensáveis para a atuação profissional, e é continuamente alterada.

Três tipos de conhecimentos relativos ao ensino são destacados por Shulman (2005), embora outros possam ser também apontados. O conhecimento de conteúdo específico diz respeito ao conhecimento de conceitos básicos de uma área, das formas de pensar e entender a sua construção, como se relacionam e como podem ser testados, avaliados e expandidos; como essas ideias e os seus fundamentos foram formulados e de que maneira se relacionam com diferentes campos de modo a poder selecionar e usar exemplos significativos, problemas e aplicações nas suas aulas (DARLING-HAMMOND, 1997). O conhecimento pedagógico geral transcende o domínio de uma área específica e inclui os conhecimentos de objetivos, metas e propósitos educacionais, de ensino e de aprendizagem, de manejo de classe e de interação com os alunos, de estratégias instrucionais, de como os alunos aprendem, entre outros. E o conhecimento pedagógico de conteúdo é específico da docência e incorpora um conjunto de tópicos relativos ao conteúdo a ser ensinado e ao modo de ensino. Diz respeito à transformação de algo a ser ensinado em algo aprendido. Este último é o único conhecimento pelo qual o professor pode estabelecer uma relação de protagonismo. É 
de sua autoria. É aprendido no exercício profissional, mas não prescinde das outras fontes como cursos, programas, estudos de teorias, etc.

Nota-se que, na composição da problemática sobre a base de conhecimento para o ensino, a formação de professores e as demandas atuais da sociedade sobre a escola, com foco cada vez mais orientado pelo conhecimento e pela tecnologia e as alternativas implementadas frequentemente pelas políticas públicas e responsáveis pelos processos de formação docente não têm apresentado resultados muito positivos, especialmente quando se considera que as necessidades formativas são diferentes para professores em início de carreira e para aqueles mais experientes. Além disso, nem sempre as características dos ambientes de trabalho são tomadas como referência nas atividades formativas propostas, dificultando a análise situada das práticas escolares e os seus desdobramentos e a exploração de soluções para as dificuldades enfrentadas a partir da compreensão das concepções sobre ensino e aprendizagem de cada professor ou grupo de professores.

Ainda nesse sentido, aspectos relativos às naturezas individual e coletiva da aprendizagem profissional da docência são às vezes ignorados. Para a implantação de qualquer política pública ou reforma, os diferentes contextos educacionais devem ser considerados, como ainda as necessidades formativas específicas dos professores. Nesse processo, parece relevante contar com configurações diversificadas de bases de conhecimento para o ensino e para ser um profissional docente, ou seja, com indicadores de desenvolvimento profissional da docência (ou níveis de proficiência).

A considerar-se a área da Educação Física Escolar, observa-se que tem sido concebida de diferentes maneiras ao longo da sua história no Brasil. Desde a sua inserção como disciplina obrigatória no ensino fundamental - com a Lei de Diretrizes e Bases da Educação (BRASIL, 1961) -, várias correntes sobre processos de ensino nessa área podem ser identificadas, bem como os conteúdos trabalhados, produzindo, em consequência, diversas concepções sobre metodologias, objetos de estudo da área e os próprios conteúdos. 
De acordo com Betti (1991), até a década de 1960, os conteúdos ensinados receberam grande influência da área médica e estiveram fortemente centrados nos movimentos ginásticos oriundos da Europa. Na década de 1980, aspectos como a eficiência esportiva, a produtividade, o alto rendimento, a competitividade, os corpos fortes e saudáveis foram nacionalmente valorizados. Segundo Darido (2003), nessa época, a maior parte das instituições de ensino superior na área da Educação Física apresentava um viés exclusivo no ensino dos esportes e as ênfases esportiva e competitiva também se encontravam vigentes nas aulas de Educação Física Escolar. Tal perspectiva também ficou conhecida na área como ensino tecnicista, no qual se enfatizava a dimensão procedimental (o que o aluno deve saber fazer) dos conteúdos escolares, ao passo que para os outros componentes curriculares, a ênfase ocorreu na sua dimensão conceitual (o que o aluno deve saber em termos cognitivos). Já a dimensão atitudinal (como o aluno deve ser e se portar diante das pessoas e nos contextos), em linhas gerais, foi desenvolvida por meio da transmissão, aos mais habilidosos, de valores como a submissão, o individualismo e o prestígio. Nesse movimento, o professor de Educação Física era considerado um técnico esportivo cuja função consistia na transmissão de um rol de exercícios pautados na fragmentação das modalidades esportivas em fundamentos "técnicos" e "táticos". Acreditava-se que, ao dominar cada um dos fundamentos da modalidade, os alunos/ jogadores conseguiriam compreender o todo" (LEAL, 2011, p. 62), isto é, o jogo esportivo.

A partir da década de 1980, a Educação Física passou a ser amplamente ressignificada e a tomar outros rumos (DARIDO, 2005): o professor responsável por esse componente curricular, até então considerado um técnico esportivo, passou a ser visto diferentemente e a sua própria formação começou a ser revista. Em decorrência desse contexto, surgiram as tendências críticas da Educação Física (BETTI, 1991; DARIDO, 2005), as quais deram um maior foco à leitura da realidade social, estimulando o questionamento (dimensão atitudinal) dos alunos, a apropriação de conhecimentos acerca da origem e do contexto (dimensão conceitual) da cultura corporal, a qual 
envolve conteúdos relacionados aos jogos, às danças, lutas, ginásticas e aos esportes, por exemplo. Contemplando as diferentes dimensões dos conteúdos, esse novo olhar da Educação Física Escolar desencadeou, de acordo com os Parâmetros Curriculares Nacionais (BRASIL, 1997, p. 21):

[...] uma mudança de enfoque, tanto no que dizia respeito à natureza da área quanto no que se referia aos seus objetivos, conteúdos e pressupostos pedagógicos de ensino e aprendizagem. No primeiro aspecto, se ampliou a visão de uma área biológica, reavaliaram-se e enfatizaram-se as dimensões psicológicas, sociais, cognitivas e afetivas, concebendo o aluno como ser humano integral. No segundo, se abarcaram objetivos educacionais mais amplos (não apenas voltados para a formação de um físico que pudesse sustentar a atividade intelectual), conteúdos diversificados (não só exercícios e esportes) e pressupostos pedagógicos mais humanos (e não apenas adestramento).

De modo específico, no que tange aos conteúdos da Educação Física Escolar, os Parâmetros Curriculares Nacionais (BRASIL, 1997) indicam que, desde o final do primeiro ciclo do ensino fundamental, espera-se que as crianças consigam participar de diferentes atividades corporais, de modo a adotar uma atitude cooperativa, solidária e que não discrimine os seus colegas, seja por motivos de desempenho ou por razões sociais, físicas, étnicas, religiosas, sexuais ou culturais. Também é esperado que conheçam e pratiquem diferentes possibilidades de movimento, buscando superar suas limitações no que se refere à cultura corporal. A valorização e a apreciação de algumas manifestações da cultura humana presentes no seu dia a dia também são esperadas das crianças dessa etapa de ensino, uma vez que, de posse desses conhecimentos, poderão organizar, cada vez mais autonomamente, suas brincadeiras, seus jogos e outras atividades de natureza coletiva.

Em relação ao ciclo II ( $3^{\mathrm{a}}$ e $4^{\mathrm{a}}$ séries) do ensino fundamental, as indicações desse documento são de que as crianças devem ser capazes de continuar com a ascensão de atitudes solidárias e de respeito mútuo, agora em situações que po- 
dem abranger, além dos jogos e das brincadeiras, os esportes, as danças e lutas, de modo a não solucionarem os seus conflitos de maneira violenta. Espera-se que consigam reconhecer e respeitar algumas características dos seus movimentos, bem como as dos seus colegas sem que haja discriminações.

Os Parâmetros Curriculares Nacionais (BRASIL, 1997) ainda apontam que os objetivos das aulas devem contribuir para a autonomia dos alunos, fazendo com que aprendam, desenvolvam e valorizem os seus movimentos, utilizando-os como recursos para a organização de atividades coletivas, para a manutenção da sua própria saúde e, ainda, para o usufruto do tempo disponível que possuem. O documento estabelece como objetivos para as aulas de Educação Física o desenvolvimento da capacidade das crianças de analisar alguns dos padrões de estética e saúde presentes no seu cotidiano, compreendendo a sua inserção no contexto em que tais padrões são produzidos para que consigam identificar e criticar aqueles que incentivam o consumismo.

Dois aspectos, nessa discussão, merecem destaque: um diz respeito à ideia de que a Educação Física Escolar não tem como função a realização de atividades idênticas àquelas que são praticadas pelos alunos fora do ambiente escolar; mas desconsiderar tais práticas no processo de ensino e aprendizagem na escola também seria um equívoco e, sobretudo, uma opressão às formas de manifestações culturais dos alunos. Outro se refere ao entendimento de que a Educação Física Escolar deve tomar como ponto de partida os conhecimentos dos próprios alunos para então avançar nos processos de ensino e de aprendizagem na escola.

Considerando as especificidades da Educação Física, pondera-se que o foco não está no "movimento" ou no "corpo" (estando este separado da mente), mas sim no sujeito do movimento (KUNZ, 1994, 2008; BETTI et al., 2010), sendo o aluno o ser humano autor dos seus próprios movimentos, associados à sua subjetividade, à sua intencionalidade, à sua história de vida e da sua própria cultura. Nesse contexto, inerente ao corpo está o movimento. Assim, a Educação Física Escolar deve ser concebida como um espaço em que os conhecimentos, as atividades, as reflexões e os conteúdos sejam 
desenvolvidos de modo próximo à realidade social e histórica dos alunos e da escola. O processo de ensino dos seus conteúdos deve contemplar, intencionalmente, o desenvolvimento da leitura, da compreensão, da reprodução, da transformação e da produção da cultura de movimento (KUNZ, 2004; BETTI et al., 2010).

Em alguns documentos sobre a área da Educação Física, como a Proposta Curricular de São Paulo (SÃO PAULO, 2008), as Diretrizes Curriculares do Paraná (PARANÁ, 2006) e a Proposta Curricular de Santa Catarina (SANTA CATARINA, 1998), evidenciam-se diferenças entre as concepções de conteúdo, corpo e cultura de movimento. Contudo, em linhas gerais, esses documentos e outros estudos (BORGES, 1998, 2005; BRACHT et al., 2003; KUNZ, 2004; FERREIRA, 2006; SANCHES; BETTI, 2008, 2010; BETTI et al., 2010, LEAL, 2011) apontam a relevância de práticas escolares desse componente comprometidas com os alunos, que promovam processos qualificados de ensino e de aprendizagem no ambiente escolar por meio de trabalhos coletivos/colaborativos. Para tanto, destacam-se o diálogo e a permanente mobilização de estratégias de ensino, recursos, conteúdos, conhecimentos, reflexões e ações em prol do ser humano.

Entende-se, ainda, que a comunidade escolar deve estar envolvida e articulada em uma cultura de trabalho coletiva/colaborativa, intencional, sistematizada, transformadora e, portanto, educativa. Cada componente curricular deve ter metas próprias, mas também objetivos comuns com os demais componentes de forma a possibilitar o qualificado desenvolvimento profissional na docência e o máximo da apropriação dos conhecimentos aos alunos. Em decorrência, pode-se pensar num conjunto de conhecimentos a serem aprendidos e desenvolvidos pelos alunos e professores por meio das aulas de Educação Física na escola. 
MAPEAMENTO DE INDICADORES DE DESENVOLVIMENTO PROFISSIONAL DA DOCÊNCIA: O CASO DE UM PROFESSOR EXPERIENTE DE EDUCAÇÃO FÍSICA ESCOLAR DAS $3^{A}$ E $4^{A}$ SÉRIES DO ENSINO FUNDAMENTAL

Especificamente, por meio da investigação aqui considerada, objetivou-se identificar indicadores educacionais de desenvolvimento profissional da docência com base nas concepções de um professor de Educação Física experiente sobre o que e por que deve saber, e em que grau de proficiência, para ensinar os seus alunos do ciclo II ( $3^{\underline{a}}$ e $4^{\text {a }}$ séries) do ensino fundamental. Para atingir tais propósitos, buscou-se ainda analisar as contingências relacionadas ao seu desenvolvimento profissional e aos processos de ensino e aprendizagem da Educação Física considerando os contextos de atuação e as relações estabelecidas com os seus pares, alunos e demais membros da comunidade escolar.

Uma vez que o problema investigado está voltado para os conhecimentos docentes e o desenvolvimento profissional na carreira, a coleta de dados e suas análises tiveram como foco a identificação de elementos que influenciaram a composição da base de conhecimento para o ensino e para ser um professor de Educação Física (pEF) investigado, tendo como ponto de partida a explicitação das suas concepções e a análise sobre as situações vividas no âmbito da docência. Para tanto, optou-se pela realização de um estudo exploratório, de natureza descritivo-analítica.

Para a escolha do professor participante, tomaram-se como base alguns estudos realizados anteriormente (LEAL; FERREIRA, 2006, 2007a, 2007b, 2008, 2009, 2011; LEAL, 2007), que buscaram mapear e descrever a experiência de professores de Educação Física e os significados por eles atribuídos às diversas situações vivenciadas, bem como identificar os elementos que as circunscreviam. Selecionou-se o pEF porque foi considerado experiente não apenas pelo seu tempo de carreira, mas por possuir vivências diversificadas em contextos variados, por atualizar-se e inovar constantemente.

Licenciado em Educação Física no ano de 1997, em uma instituição de ensino superior de uma cidade do interior de 
São Paulo, o pEF atuou durante sete anos (de 1994 a 2001) como monitor esportivo. Em 2001, iniciou a sua carreira como professor efetivo em uma escola estadual de outra cidade do interior. Por aproximadamente três anos, em razão de uma indicação/convite para o cargo, deixou de ministrar aulas na escola para ser assistente técnico-pedagógico (ATP). Em 2004, o pEF retornou às escolas atuando na rede estadual numa outra cidade paulista. Em 2005, mudou de cidade e passou a ministrar aulas em escolas estaduais e municipais, com uma carga horária de 50 aulas semanais. No ano de 2006, frequentou quinzenalmente um grupo de estudos sobre Educação Física Escolar numa universidade pública. Em 2007, mudou mais uma vez de escola e, com o objetivo de continuar aprimorando-se profissionalmente, desde 2010 cursa Pedagogia, na modalidade semipresencial, em uma universidade pública no interior de São Paulo.

Antes do início da coleta de dados, realizaram-se visitas a uma das instituições em que o pEF lecionava com o intuito de aproximar-se do seu contexto de trabalho; observar as suas aulas (24 no total, com duração de 1 h40min cada), ao longo de quatro meses; identificar algumas rotinas; conhecer as dependências e estruturas físicas da instituição e as características da comunidade na qual a escola estava inserida. Essas visitas possibilitaram reconhecer a presença de elementos diferenciadores de atuação profissional, configurando-o como um professor experiente.

Foram realizadas três entrevistas semiestruturadas (MINAYO, 1993; LAKATOS; MARCONI, 1996), com intervalo de aproximadamente 40 dias porque, sendo de natureza aberta, permitiram maior liberdade de manifestação do pEF. Todas as entrevistas foram gravadas e totalizaram aproximadamente seis horas de gravação. Adotou-se como sistemática entregar uma transcrição da entrevista anterior para o pEF, de forma que fosse possível analisar as respostas apresentadas e possibilitar-lhe retirá-las, alterá-las ou complementá-las conforme julgasse necessário, de modo a não haver equívocos na descrição das suas concepções ou de outras informações ou a não constrangê-lo por alguma informação que considerasse inapropriada. Além disso, cada uma das três entrevistas deu 
origem a um quadro em que se buscou categorizar e expor o cerne das respostas do participante. Com base na frequência de aparecimento ao longo das entrevistas e na proximidade das ideias, foi possível construir os focos de análise dos elementos relativos ao tema da pesquisa.

A primeira entrevista abordou os seguintes tópicos: conhecimentos que os alunos devem ter no que se refere à Educação Física Escolar nos anos iniciais e, ainda, como a comunidade escolar mobilizava-se em meio ao processo de aprendizagem desses conteúdos; base de conhecimento para a docência no âmbito da Educação Física Escolar, particularmente os conhecimentos pedagógicos e específicos do conteúdo, de acordo com a sua trajetória profissional; ações da comunidade escolar que auxiliam o processo de ensino dos conteúdos da Educação Física e o desenvolvimento profissional da docência; desenvolvimento profissional do $\mathrm{pEF}$ ao longo da carreira e no seu contexto de trabalho.

A segunda entrevista foi realizada com base nos dados da primeira entrevista e, para a sua realização, junto à transcrição entregou-se um resumo com as ideias/elementos centrais das respostas a cada questão da primeira, para que as concepções ali sintetizadas também fossem revistas pelo $\mathrm{pEF}$.

Já a terceira entrevista teve como enfoque a identificação das concepções referentes aos conhecimentos que o professor deve dominar, mobilizar e operacionalizar para que possa ensinar os conteúdos da Educação Física aos alunos do ciclo II. Além disso, também foi possível identificar os objetivos educacionais estabelecidos pelo pEF para esses alunos.

Para a análise do material coletado, as concepções do pEF foram organizadas e classificadas em três categorias: 0 que os alunos devem aprender; o que o professor deve saber para ensinar e o que a comunidade escolar deve fazer para auxiliar alunos e professores no processo de aprender e ensinar nas aulas. Com base nessas três categorias, elaboraram-se/construiram-se os indicadores educacionais de desenvolvimento profissional do $\mathrm{pEF}$, em função do seu contexto específico de atuação com o ciclo II do ensino fundamental e de aspectos próprios da sua trajetória profissional. 


\section{OS ALUNOS: O QUE DEVEM APRENDER}

Sobre esse aspecto, o pEF relatou que as turmas de $1^{\mathrm{a}}$ a $4^{\mathrm{a}}$ séries são divididas em dois ciclos porque o próprio documento dos Parâmetros Curriculares Nacionais (BRASIL, 1997) faz essa separação. Assim, no ciclo I do ensino fundamental, estão os alunos das $1^{\mathrm{a}}$ e $2^{\mathrm{a}}$ séries e no ciclo II, os alunos das $3^{\mathrm{a}}$ e $4^{\mathrm{a}}$ séries. De igual modo, os temas e os conteúdos nas aulas são planejados/estruturados em função de tal divisão: o professor desenvolve um conjunto de conteúdos, habilidades e conhecimentos com o ciclo I e outro conjunto com o ciclo II, tendo este último um caráter de ampliação e aprofundamento em relação ao primeiro.

As estratégias de ensino e dinâmicas utilizadas nas aulas de Educação Física com os alunos dos ciclos I e II do ensino fundamental procuram favorecer o conhecimento do corpo na relação/interação e organização entre os próprios alunos, por meio de atividades realizadas em pequenos e grandes grupos e com o auxílio de materiais como cordas, bolas de diferentes tamanhos, raquetes de madeira e bexigas, por exemplo. O pFE afirmou que nas aulas busca diversificar ao máximo as atividades desenvolvidas e os materiais utilizados pelos alunos. Além disso, procura tornar ampla a vivência nas atividades propostas, construindo, mobilizando e organizando, para tanto, estratégias com vistas a otimizar o tempo de aula e aumentar a participação dos alunos. Afirma que em muitos casos observa

[...] o professor batendo corda para o aluno e uma fila indiana a perder de vista. Então nesse [exemplo], ele [o aluno] chega ao final da aula, mesmo enfatizando o aspecto prático, ele participou uma ou duas vezes apenas. (pEF - Entrevista 1)

Para o pEF, a Educação Física possui uma série de conhecimentos que podem ser explorados e desdobrados pedagógica e didaticamente nas aulas dentro do ambiente escolar. Na sua perspectiva:

\footnotetext{
[...] a Educação Física Escolar não é só bola. Existe uma gama de atividades que [os alunos] precisam participar, desenvolver, para que futuramente possam adquirir outros conhecimentos, inclusive do ponto de vista motor e do ponto de vista intelectual. (pEF - Entrevista 1)
} 
Informações relacionadas a o que, por que e em que medida os alunos do ciclo II devem saber sobre a Educação Física Escolar foram destacadas pelo pEF: ações como o aprender, o refletir e o estudar. A sua atuação direciona-se para possibilitar que esses objetivos sejam alcançados:

[...] então, se a Educação Física está inserida no contexto escolar, só se justifica a presença dela ali se ela tiver um propósito de fazer com que esse aluno aprenda, reflita e estude. Eu penso assim e eu direciono meu trabalho para isso. (pEF - Entrevista 3)

Para o pEF, o rol de conteúdos deve possibilitar que o aluno aprenda conhecimentos que fazem parte do seu cotidiano bem como outros, de modo a ampliar o seu repertório acerca da cultura de movimento. Destaca que as aprendizagens de conteúdos, numa determinada série, facilitam a compreensão dos conteúdos das séries posteriores, em que serão retomados e ampliados.

Segue uma síntese (Quadro 3) do que, na sua perspectiva, os alunos do ciclo II devem saber. Nas suas respostas, foi possível verificar que são diversificados os temas e os conteúdos que podem ser desenvolvidos sem ser necessária apenas a realização das modalidades esportivas, uma vez que os esportes são apenas um dos conteúdos desse componente. De acordo com o pEF, os conteúdos por ele ministrados são organizados por temas. Justifica esse tipo de organização por possibilitar uma melhor articulação entre os diversos elementos/conteúdos da Educação Física.

Nas suas respostas, percebe-se ainda que as aprendizagens a serem construídas pelos seus alunos abarcam conteúdos conceituais e atitudinais, superando uma perspectiva de ensino majoritariamente procedimental. Além disso, o professor participante aponta a importância da reflexão nesse processo:

Mas não só enfatizo os conteúdos conceituais (como o tema emagrecimento). E a prova disso foi o tema que eu desenvolvi sobre os comportamentos e os conflitos, isso na minha concepção também é um estudo, essa reflexão sobre a prática você provoca aprendizagem [aos alunos] 
[...]. Então é essa soma de conteúdos que, ao terminar o ciclo escolar, ele [o aluno] terá minimamente condições para, de repente, discutir, refletir sobre a mídia (por que hoje a televisão fala coisas, vende muita publicidade e às vezes é só financeira e não é o aspecto da saúde que está em jogo), então ele tem essa condição de fazer essa reflexão um pouquinho mais aprofundada [...]. (pEF- Entrevista 3)

\section{QUADRO 3 - Conteúdos da Educação Física para o ciclo II do ensino fundamental}

\begin{tabular}{|c|c|c|}
\hline CONTEÚDOS & JUSTIFICATIVA & GRAU DE PROFICIÊNCIA \\
\hline $\begin{array}{l}\text { Tema: Hidratação e desidratação } \\
\text { - Conceitos de hidratação e desidratação. } \\
\text { - Principais cuidados. } \\
\text { - A importância dos intervalos dos jogos. } \\
\text { - Conceito de atividade física. } \\
\text { - A relação entre atividade física e desidratação. } \\
\text { - Meios de eliminação de água do organismo. }\end{array}$ & $\begin{array}{l}\text { Conhecimentos básicos que, } \\
\text { somados aos conhecimentos } \\
\text { adquiridos no ciclo II e no } \\
\text { ensino médio, permitirão uma } \\
\text { busca autônoma de uma vida } \\
\text { de qualidade. }\end{array}$ & $\begin{array}{l}\text { Conhecimento e consciência da } \\
\text { importância da ingestão de água no } \\
\text { dia a dia, principalmente durante e } \\
\text { após a prática de atividades físicas. }\end{array}$ \\
\hline $\begin{array}{l}\text { Tema: Frequência cardíaca I } \\
\text { - Conceitos de frequência cardíaca, artéria e veia. } \\
\text { - Pontos de verificação da frequência cardíaca. } \\
\text { - Verificação da frequência cardíaca em repouso e } \\
\text { em movimento. }\end{array}$ & $\begin{array}{l}\text { Conhecimentos básicos que, } \\
\text { somados aos conhecimentos } \\
\text { adquiridos no ciclo II e no } \\
\text { ensino médio, permitirão uma } \\
\text { busca autônoma de uma vida } \\
\text { de qualidade. }\end{array}$ & $\begin{array}{l}\text { Percepção de que o coração pode } \\
\text { ser sentido em várias partes do } \\
\text { corpo e início de uma superficial } \\
\text { relação entre batimento cardíaco e } \\
\text { atividade física. }\end{array}$ \\
\hline $\begin{array}{l}\text { Tema: Frequência cardíaca II } \\
\text { - Conceito de atividade física. } \\
\text { - Aparelhos circulatório, muscular e celular. } \\
\text { - A relação entre frequência cardíaca, corpo em } \\
\text { repouso e atividade física. } \\
\text { - Verificação da frequência cardíaca em repouso e } \\
\text { em movimento. }\end{array}$ & $\begin{array}{l}\text { Conhecimentos básicos que, } \\
\text { somados aos conhecimentos } \\
\text { adquiridos no ciclo II e no } \\
\text { ensino médio, permitirão uma } \\
\text { busca autônoma de uma vida } \\
\text { de qualidade. }\end{array}$ & $\begin{array}{l}\text { Aprofundamento dos } \\
\text { conhecimentos adquiridos no tema } \\
\text { frequência cardíaca l, ampliando as } \\
\text { relações existentes entre atividade } \\
\text { física, frequência cardíaca e } \\
\text { aparelho muscular e respiratório. }\end{array}$ \\
\hline $\begin{array}{l}\text { Tema: As capacidades físicas } \\
\text { - Força; resistência; coordenação motora; equilíbrio; } \\
\text { velocidade; flexibilidade; agilidade; ritmo. }\end{array}$ & $\begin{array}{l}\text { Conhecimentos básicos que, } \\
\text { somados aos conhecimentos } \\
\text { adquiridos no ciclo Il e no } \\
\text { ensino médio, permitirão uma } \\
\text { busca autônoma de uma vida } \\
\text { de qualidade. }\end{array}$ & $\begin{array}{l}\text { Conhecimento e diferenciação } \\
\text { de diversas capacidades físicas e } \\
\text { percepção de sua aplicação nas } \\
\text { atividades práticas. }\end{array}$ \\
\hline $\begin{array}{l}\text { Tema: Ritmo e dança } \\
\text { - Conceito de ritmo. } \\
\text { - Vivência de vários gêneros musicais. }\end{array}$ & $\begin{array}{l}\text { Ampliação do repertório } \\
\text { motor. }\end{array}$ & $\begin{array}{l}\text { Conhecimento sobre os vários } \\
\text { gêneros musicais. }\end{array}$ \\
\hline $\begin{array}{l}\text { Tema: Danças folclóricas } \\
\text { - Danças regionais. } \\
\text { - Danças brasileiras. }\end{array}$ & $\begin{array}{l}\text { Ampliação do conhecimento } \\
\text { sobre as danças regionais } \\
\text { brasileiras. }\end{array}$ & $\begin{array}{l}\text { Conhecimento de algumas danças } \\
\text { regionais brasileiras e de suas } \\
\text { peculiaridades. }\end{array}$ \\
\hline $\begin{array}{l}\text { Tema: Jogos e brincadeiras II } \\
\text { - Pesquisa sobre jogos e brincadeiras populares. } \\
\text { - Formação de grupos para a apresentação de jogos } \\
\text { e brincadeiras. }\end{array}$ & $\begin{array}{l}\text { Resgate dos jogos e das } \\
\text { brincadeiras populares. }\end{array}$ & $\begin{array}{l}\text { Conhecimento dos jogos e das } \\
\text { brincadeiras populares. }\end{array}$ \\
\hline $\begin{array}{l}\text { Tema: Atividades pré-desportivas } \\
\text { - Conceitos de atividade pré-desportiva e de esporte. } \\
\text { - Conhecimento de vários esportes por meio de } \\
\text { vídeos. } \\
\text { - Conhecimento na prática das diferenças entre o } \\
\text { esporte e a atividade pré-desportiva. } \\
\text { - Vivência de várias atividades pré-desportivas. }\end{array}$ & Iniciação ao esporte. & $\begin{array}{l}\text { Conhecimento sobre diversos } \\
\text { esportes e suas possíveis } \\
\text { adaptações. }\end{array}$ \\
\hline
\end{tabular}

Fonte: pEF - Entrevista 2 
Por meio das suas manifestações, pode-se identificar a intencionalidade do professor em atuar qualificadamente a fim de mediar a apropriação dos conteúdos pelos seus alunos nas dimensões procedimental, conceitual e atitudinal. A sua preocupação com a articulação entre essas dimensões e, ainda, entre a Educação Física e os demais componentes curriculares também foi observada.

De modo geral, o conjunto de conhecimentos a serem construídos pelos alunos nas aulas, segundo o pEF, tem como finalidade a apropriação de conhecimentos para a vida, possibilitando experienciar de forma autônoma e crítica diferentes contextos, além de favorecer a reflexão sobre aquilo que praticam. Para tanto, busca diversificar conteúdos, atividades e a sua própria forma de atuação:

É diversificar o máximo possível, dentro dessa gama de atividades e conteúdos que hoje são propostos para serem trabalhados na Educação Física, desde lutas - inclusive tive dificuldades pra trabalhar a capoeira recentemente - até as brincadeiras de esconde-esconde, enfim. Mas procurando diversificar o máximo. Pra quê? Para possibilitar que esse aluno, dentro do seu repertório motor, para que ele possa, no futuro, se ele tiver interesse, buscar um aperfeiçoamento, mas pelo menos pra que ele tenha conhecimento. (pEF - Entrevista 1)

A diversidade na oferta de atividades é bastante valorizada pelo pEF nas aulas que ministra. Essa variedade também proporciona aos seus alunos maiores possibilidades de relação com os aspectos conceituais, incluindo aqueles que não fazem parte do seu cotidiano, de maneira a ampliar o seu repertório cultural. A seguir, o participante descreve a trajetória de aprendizagem dos seus alunos desde o ciclo I até o ciclo II do ensino fundamental:

[...] ao longo desse ciclo [1ª e $2^{a}$ séries $]$, o aluno estará vivenciando as mais variadas atividades, o movimento... enfim, é claro, pensando no aspecto físico, nas habilidades físicas, manipulação, locomoção, das capacidades físicas, habilidade, agilidade, força, equilíbrio... É nesse sentido que eu tenho trabalhado. Já nas $3^{a}$ e $4^{a}$ séries, 
a prática tem uma relação com a teoria discutida em sala de aula [...]. Então o que estava previsto para o ciclo II... aqueles temas, muitos deles eu já trabalhei o ano anterior. Trabalhei com jogos e brincadeiras, então eu já não estou trabalhando mais com eles esse ano. [...] No momento, estou abordando o tema "hidratação e desidratação", por exemplo, na quarta série. Então começamos a discutir em sala de aula sempre um tópico do tema para não estender muito essa aula de Educação Física [...] e depois já vamos para prática. Eu sempre deixo uma perguntinha no ar para a próxima aula, ou até mesmo para responder durante a atividade prática... Como nós estamos falando do tema hidratação e desidratação, eu desenvolvi duas atividades e deixei uma pergunta para a aula seguinte: qual dessas duas atividades poderia desidratar mais uma pessoa? Mas antes, é claro, discutimos o que é hidratação e desidratação... e é nesse sentido que eu tenho trabalhado. (pEF - Entrevista 1)

Evidencia-se que, para ensinar um novo conteúdo, o pEF usualmente considera os conhecimentos que os alunos já possuem e também promove um processo de reflexão que se inicia a partir da introdução de um tema, se estende até concluí-lo ao longo das aulas e, ainda, proporciona aos alunos a possibilidade de relacioná-las com as suas atividades cotidianas, com a perspectiva de avançar em relação ao que sabiam inicialmente. Essa mediação atenciosa e comprometida se torna fundamental para que os alunos apropriem-se da cultura de movimento nas suas aulas de Educação Física.

\section{OS PROFESSORES: O QUE DEVEM SABER PARA ENSINAR}

Para o pEF, um aspecto relevante refere-se à necessidade de o professor ter clareza dos objetivos, isto é, de saber aonde quer "chegar" com os conteúdos desenvolvidos nas aulas. No seu ponto de vista, tal postura se aplica independentemente da metodologia ou da concepção teórica de ensino adotada pelo profissional. Menciona que, no início da carreira, 
durante todo o período em que ministrava aula numa perspectiva tecnicista/esportivista, tinha conviç̧ão de que os seus alunos deveriam aprender os gestos técnicos dos esportes e os fundamentos específicos de cada modalidade. Portanto, com base nessa concepção, as estratégias de ensino escolhidas focavam-se em tal finalidade. Nas palavras do pEF:

[...] o professor tem que ter clareza disso, então, por exemplo, eu me lembro do meu início: quando eu era tecnicista, acredito que fazia muito bem aquilo. Não vou dizer se estava certo ou se estava errado, mas o importante é sua prática, sua postura estar bem... ser bem consistente com relação aos seus objetivos... Então, costumo dizer o seguinte: seria melhor hoje, apesar de condenado por muitos, essa questão do tecnicismo, $[. .$.$] eu ainda sou da$ seguinte opinião: se houvesse professores que trabalhassem de maneira... tecnicista, mas que trabalhassem realmente... fundamentados dentro desses princípios, com um trabalho qualificado, consistente, seria melhor do que está hoje [...]. Então hoje você encontra o quê? O professor que dá a bola pros alunos e fica ali [...] olhando se terminou, controlando o tempo. A hora que deu o tempo, ele recolhe o material, pega a outra turma, distribui o material... é uma distribuição de material, isso é o que a gente tem e, infelizmente, o que eu tenho visto. Essa é a realidade, apesar de os professores não gostarem muito quando a gente fala isso numa reunião, por exemplo. (pEF - Entrevista 1)

Mesmo considerando que o tecnicismo/esportivista é hoje uma concepção teórico-metodológica ultrapassada para o processo de ensino nas aulas de Educação Física Escolar, para o pEF, se ao menos os docentes ainda atuassem realmente embasados nela, os alunos aprenderiam algo planejado, com direcionamento/mediação profissional e, assim, haveria objetivos e finalidades a serem alcançados e os docentes teriam parâmetros para avaliar e replanejar o processo de ensino das suas aulas e de aprendizagem dos seus alunos. 
Vale destacar que essa perspectiva educativa, que contempla metas e objetivos por meio de um processo de ensino pedagogicamente qualificado, é aquela que se concebe como necessária para toda e qualquer ação educativa no contexto escolar. Nesse sentido, os relatos do pEF vão ao encontro, por exemplo, do que afirma Imbernón (2001, p. 35):

El docente deberá apoyar sus acciones en una fundamentación válida para evitar caer en la paradoja de enseñar a no enseñar, o en una falta de responsabilidad social y política que conlleva todo acto educativo, y en una visión funcionalista, mecánica, rutinaria y no reflexiva de la profesión que ocasiona un bajo nivel de abstracción, de actitud reflexiva y un escaso potencial de aplicación innovadora.

No entanto, o pEF indica que o problema não está apenas na ausência de compromisso dos docentes, de modo a responsabilizá-los individualmente por um problema que é construído social e historicamente. A dificuldade é bem mais ampla e abrange vários outros segmentos, como as políticas públicas em educação e os próprios cursos de formação inicial de professores. Para ele, as licenciaturas em Educação Física poderiam contribuir muito mais para a formação dos professores se houvesse um melhor desenvolvimento dos conteúdos no que tange aos aspectos didático-metodológicos, isto é, elementos que se relacionem ao como ensinar:

[...] eu fiz a licenciatura plena. Então se subentende que meu curso deveria, ao trabalhar os esportes, por exemplo - porque tem lá na grade o voleibol, o basquete 1, o basquete 2 , natação 1 e aí vai... -, dar uma ênfase no ponto de vista didático-metodológico voltado para o escolar. Então isso não é visto na faculdade, pelo menos não na minha experiência. Então o que foi visto? Foi visto a questão técnica, tática [...] na verdade, isso aí vai de cada aluno [graduando], mas ali não se deu a ênfase nas maneiras de abordar esses conteúdos na escola. Isso não foi trabalhado. Acho que é nisso que a faculdade está pecando. Então, por exemplo, se vai trabalhar o voleibol: como nós poderíamos trabalhar o voleibol de primeira a quinta/quarta série? E destrinchar todas as possibilidades... 
claro que fundamentado em algumas teorias, mas [...] que de que maneira prática nós poderíamos estar abordando esta questão? (pEF - Entrevista 1)

Observa-se que as respostas do pEF se referem frequentemente aos conhecimentos que os docentes devem possuir, mobilizar e operacionalizar para ensinar e exercer a profissão na escola, ou seja, a base de conhecimento para o ensino (SHULMAN, 1989, 2005) e para uma atuação profissional. Ao apontar que o professor de Educação Física deve saber aspectos didático-metodológicos acerca do conteúdo a ser ensinado, por exemplo, pode-se visualizar a necessidade de dominar o conhecimento pedagógico do conteúdo. Nas suas respostas, evidenciam-se vários outros domínios que constituem a base de conhecimento para o ensino. Alguns exemplos são:

[...] então ele [o professor] tem que ter conhecimento de estratégia metodológica, de didática, tem que ter isso bem solidificado, isso dá um suporte, uma segurança no trabalho. Por exemplo, como é que eu vou trabalhar com leitura na aula de Educação Física, então antes dele se propor esse trabalho, e olha não é conteúdo, é didática, estratégia, quais recursos eu vou utilizar? (pEF - Entrevista 3, grifo nosso)

[...] trabalhei o conteúdo "Exercício físico e atividade física”, os conceitos de atividade física e exercício físico pra mostrar. Então antes até para esse tema eu tive que elencar vários conteúdos e um amarrado com o outro, então isso não é tão simples assim... (pEF - Entrevista 3, grifo nosso)

Conhecimentos de aspectos metodológicos e didáticos são apontados pelo professor como saberes importantes para o ensino da Educação Física, abrangendo a possibilidade de uso de diferentes recursos e estratégias para facilitar o aprendizado do aluno, tais como vídeos sobre o tema abordado, slides, datashow, recortes da internet, filmagens das próprias aulas. Também cita a adaptação de conceitos e conteúdos, de modo a utilizar uma linguagem acessível aos alunos.

Para o pEF, é extremamente importante a verificação das aprendizagens dos alunos na Educação Física Escolar. Para tanto, o 
docente deve realizar avaliações conceituais, comparando o que os alunos sabiam inicialmente e o que sabem após o desenvolvimento dos conteúdos; observar as atitudes dos seus alunos nas aulas; e, ainda, observar sistematicamente a evolução do desenvolvimento motor dos alunos, utilizando atividades lúdicas que também possibilitem a reflexão sobre as suas aprendizagens.

O planejamento sistemático das aulas se configura como outro recurso valioso para o bom andamento das aulas porque auxilia a organização dos conteúdos considerando a distribuição temporal das atividades (começo, meio e fim). No entanto, ressalta que o planejamento é um guia e que, por isso, se ocorrerem imprevistos, fica mais fácil alterá-lo e reorganizar as atividades caso seja preciso, indicando, portanto, a necessidade de saber usá-lo. Por sempre tentar perceber, refletir, avaliar e rever a sua prática pedagógica, o pEF apresentou ter maiores possibilidades de compreender a dinâmica das aulas, os seus alcances, dificuldades e, assim, buscar estratégias para superá-las quando preciso. Seguem exemplos apresentados por ele:

[...] se eu dei a aula e sinto no momento que não tive sucesso [...], percebi que havia uma barreira e não foi legal, fui infeliz na escolha, no encaminhamento que dei e só fui descobrir depois..., na outra aula eu tirei de letra. [...] Pode surgir questionamento de aluno sobre um tema que o professor não tenha resposta, e eu acredito que isso é natural, eu acredito que ele tem que depois procurar e tentar mostrar... a resposta do questionamento. (pEF - Entrevista 3)

A reflexão a seguir aponta ainda a importância de o professor conhecer as necessidades dos alunos, as suas dúvidas e dificuldades:

[...] o tema do projeto era Atividade pré-esportiva: novos horizontes para a convivência harmoniosa nos esportes, porque eu percebi que nas três quartas séries havia um indice bem mais baixo, um médio e, na outra mais ainda, um índice elevado de discussão ou de conflito na prática. (pEF - Entrevista 3) 
Segundo o pEF, as formas de organizar, mobilizar e operacionalizar os conteúdos foram construídas com base na sua experiência profissional, nas suas pesquisas, leituras e nos conhecimentos adquiridos nas vivências com os seus alunos. De um modo geral, busca entrelaçar os conteúdos com os objetivos almejados em função dos conhecimentos das suas turmas, possibilitando reflexões, debates e conhecimentos focados na vida dos alunos fora da escola:

[...] pelo menos eu tenho essa visão [...] e o que acontece, essa criança, ela convive ali comigo quanto tempo? Cinquenta minutos, duas aulas ou 100 minutos por semana. Ela tem uma convivência muito maior com outras pessoas, com outra comunidade, com a rua [...]. Então a intenção inicial não é transformar, mas... fazer com que ela refletisse sobre aquilo, que tivesse uma oportunidade porque, se não fosse, eu tenho certeza que ela não vai ter essa oportunidade. (pEF - Entrevista 3)

Para o pEF, o professor de Educação Física deve atuar de maneira consistente, mantendo compromisso com os seus alunos:

[...] eu mencionei a questão do professor, o profissional ele tem que ter uma regularidade, agora me veio a palavra, a regularidade no trabalho [...], não basta você fazer um projeto, apresenta e depois volta para a rotina bola de futebol para os meninos, entendeu? (pEF - Entrevista 3)

Isto é, a atuação profissional deve estar qualificada não apenas na fala, no discurso, nos projetos, mas também no dia a dia das aulas junto aos alunos. Para tanto, declara ser necessário o apoio da equipe técnica, pedagógica e de toda a comunidade escolar, aspecto que será abordado a seguir.

\section{A COMUNIDADE ESCOLAR: COMO DEVE SE MOBILIZAR}

Considera-se importante reconhecer a complexidade da atuação profissional de professores e, por isso, torna-se necessário saber como estabelecem elos com a comunidade em que atuam, como agem para mantê-los, como trabalham os 
conflitos inevitáveis de relacionamento social e constroem as estruturas para sustentar os relacionamentos ao longo do tempo (GROSSMAN; WINEBURG, 2000).

Nas suas respostas, o pEF menciona trabalhos que aproveitam espaços dentro e fora da escola - como sauna, academia e praças - ampliando e diversificando as possibilidades de aprendizagem, bem como a interação dos alunos em outros espaços de convivência social nos perímetros da cidade onde vivem. Destaca, ainda, um trabalho realizado com crianças e familiares:

[...] eu fiz aquela prova de atletismo na praça, eu fiz de arremesso de disco, de cabo de vassoura que é o dardo, os saltos com o trampolim e no final do projeto eu tinha a proposta de interação com a família, que foi também outra experiência nova. Lancei, agora no final do ano, em novembro, um torneio à noite para que os pais participassem. Então a regra era a seguinte: [como] íamos disputar o raquetebol e o pingbol, eu bolei uma regra de duplas e foi muito legal que joguei com aquelas bolas que usa para decorar, de plástico... que é de tamanho menor. Era assim: cada hora, um da dupla tem que rebater e ir revezando, deixando [a bola] pingar. E, a princípio, eu achei que não ia dar certo.. até experimentei antes, será que dará certo? Uma coisa é imaginar - é que nem eu falo: prever é fácil! -, praticar é outra. Então eu testei, nós improvisamos, chamei um professor, um rapaz, dois amigos e falei: vamos fazer um teste aqui. Coloquei a mesa lá e fomos rebater. Aí vi que funcionou. Falei: agora vou aplicar com as crianças e, se pegarem o jeito, vai dar certo. Então no final do torneio você tinha que trazer um adulto de casa para ser o seu parceiro, já que não podia ser nenhum aluno da escola. (pEF - Entrevista 3)

Aponta a necessidade de analisar criticamente a prática pedagógica dos demais profissionais da comunidade escolar para que os próprios alunos não sejam prejudicados. Os conhecimentos construídos durante a prática pedagógica docente estão circundados por contingências que, com o passar do tempo, podem melhor embasar e oferecer significados às suas decisões e ações no contexto escolar. O exercício reflexivo, as 
transformações das suas estratégias de ensino, a aprendizagem com os seus alunos, a relação com os seus pares e demais membros da comunidade escolar são alguns exemplos dessas contingências.

Segundo o participante, há casos em que um professor descomprometido:

[...] faz um projeto, é premiado "professor do ano" e aí?

[...] E a sua prática? Condiz? [...] Por isso, eu acredito também na questão da seleção. Selecionar um projeto só? Fez, muito bem feito, mas a minha proposta é com a Educação Física Escolar, o cotidiano, essa regularidade é o que falta em termos de seguimento de trabalho. (pEF - Entrevista 3)

Para o pEF, não basta que os professores de Educação Física se atualizem, busquem novos conhecimentos, reflitam sobre a sua atuação nas aulas, no intento de que estas sejam contextualizadas aos seus alunos se, juntamente, não houver apoio e incentivo da comunidade escolar como um todo. Recorrentemente na sua fala, encontram-se questionamentos direcionados à participação e à forma de interação entre os gestores da escola, os demais professores e a própria família dos alunos.

Com base na consideração da importância dos processos de troca, transformação e construção de conhecimentos de modo coletivo, em que as pessoas envolvidas refletem e dialogam sobre as suas ideias e concepções em meio às relações estabelecidas, defende-se que as conquistas, as dúvidas e as concepções pedagógicas dos professores e dos demais membros da instituição de ensino são instrumentos relevantes para a promoção de processos profissionais coletivos de desenvolvimento da docência e, de igual modo, para o sucesso escolar dos alunos.

\section{OS INDICADORES EDUCACIONAIS DE DESENVOLVIMENTO PROFISSIONAL IDENTIFICADOS NO PEF E ALGUMAS IDEIAS FINAIS}

A partir da ideia de que os indicadores educacionais "têm a função principal de descrever, de modo aproximado, o que ocorre numa dada realidade educacional tendo em vista 
alguns critérios previamente definidos num dado período de tempo" (REALI, 2001, p. 85), compreende-se que devem conter ou suscitar a busca de informações relevantes para a compreensão dos processos de ensino, de aprendizagem e do desenvolvimento profissional da docência. Nesse sentido, a sua elaboração e definição também devem contemplar a melhoria desses processos, indicando, por exemplo, as relações estabelecidas entre os membros de cada contexto educativo e, ainda, como essas relações vêm se modificando ao longo do tempo.

Concebem-se os indicadores de processo como recursos importantes para a definição e a avaliação de metas de ensino de cada comunidade escolar, específicas para cada componente curricular e do desenvolvimento profissional dos docentes. No presente estudo, enfatizou-se a sua importância para a identificação de características da atuação bem-sucedida de um professor experiente de Educação Física Escolar, possibilitando melhor compreender, com base nos resultados obtidos, como se estruturou o seu desenvolvimento profissional na docência.

Em função dos focos adotados para analisar os dados e considerando o contexto de atuação do pEF, objetivou-se elaborar indicadores educacionais a respeito do seu processo de desenvolvimento profissional, considerando a sua atuação no ciclo II ( $3^{\mathrm{a}}$ e $4^{\mathrm{a}}$ séries) do ensino fundamental em uma escola em particular. Os indicadores educacionais definidos ora se configuram como indicadores mais gerais, no âmbito da educação, ora como característicos da área da Educação Física, pois alguns transcendem aqueles específicos dessa área de conhecimento, como os apontados a seguir:

- Preocupação e mobilização constantes para ensinar os alunos a aprender conteúdos específicos da área da Educação Física, utilizando/solicitando/construindo diversos recursos, equipamentos, materiais e estratégias em conformidade com os objetivos estabelecidos.

- Adoção, como ponto de partida para o desenvolvimento do conteúdo, dos conhecimentos que os alunos possuem sobre as suas experiências no mundo, dentro e fora do ambiente escolar. 
- Conhecimento dos seus alunos e da realidade em que vivem.

- Mobilização, operacionalização e adequação dos seus conhecimentos às necessidades dos seus alunos e às características do contexto de atuação.

- Monitoração, identificação, avaliação dos problemas relativos aos processos de ensino e de aprendizagem e de formas de superação presentes no seu contexto de atuação e no sistema educacional como um todo.

- Articulação da Educação Física com os demais componentes curriculares presentes na escola.

- Comprometimento com a aprendizagem e o sucesso escolar dos seus alunos por meio da maximização e potencialização dos processos de apreensão e apropriação dos conteúdos da Educação Física.

- Desenvolvimento de diferentes estratégias, utilização de exemplos diversificados, otimização do tempo e ampliação dos espaços de aprendizagem para outros ambientes relacionados ao cotidiano dos alunos dentro e fora da escola.

Destaca-se que a compreensão sobre a constituição qualificada da experiência e do desenvolvimento profissional na docência aqui defendida não se pautou em uma matriz estritamente cronológica e individual do pEF: considerou, dentre outros elementos, a intencionalidade exercida pelos docentes e demais membros da comunidade escolar no ato educativo, o compromisso com a aprendizagem dos alunos, a formação qualificada, o trabalho e apoio coletivo/colaborativo, bem como o processo reflexivo docente individual e coletivo.

Cabe à comunidade escolar, com apoio das políticas públicas, propiciar e requerer espaços, meios e períodos adequados para a construção dos processos de ensino, aprendizagem e desenvolvimento profissional dos seus docentes. Assim, torna-se importante estabelecer critérios de análise, parâmetros e referências que forneçam informações contextualizadas. Por isso, os indicadores de processo, como os propostos, podem auxiliar na definição, na construção e na verificação de metas, conteúdos e objetivos específicos 
de cada comunidade escolar tendo em vista as características do seu corpo docente.

Embora a investigação tenha abordado a atividade de um profissional cuja atuação se refere a um componente específico, evidencia-se que, em virtude da prática do pEF em articular os conteúdos de uma área com o de outras, compreender como se configura o conhecimento do conteúdo específico da área da Educação Física se mostrou tarefa complexa. Aparentemente, alguns professores apresentam um tipo de conhecimento funcional de difícil apreensão, já que sabem o que ensinam, mas nem sempre a sua explicitação se mostra uma tarefa trivial, como no caso estudado. É, pois, relevante investir na compreensão e no desenvolvimento das relações entre conhecimentos tácitos e formais (POULSON, 2001).

Considerando-se que a base de conhecimento para o ensino e para a atuação de modo profissional é situada, isto é, sua configuração relaciona-se estreitamente ao contexto de atuação docente, é necessário investir na definição de conteúdos, bem como em ações formativas específicas - ainda em cursos de formação inicial - para possibilitar que os professores se ajustem às características dos seus alunos, das escolas e da comunidade escolar em geral e com o apoio da escola invistam no seu desenvolvimento profissional permanente. Pode-se afirmar que os indicadores de desenvolvimento profissional da docência, conforme apresentados, podem favorecer tais iniciativas e orientar políticas e ações de formação continuada de professores.

\section{REFERÊNCIAS}

BERLINER, David. Learning about and learning from expert teachers. International Journal of Educational Research, v. 35, n. 5, p. 463-482, 2001.

BETTI, Mauro. Educação física e sociedade. São Paulo: Movimento, 1991.

BETTI, Mauro et al. A proposta curricular de educação física do estado de São Paulo: fundamentos e desafios. In: CARREIRA FILHO, Daniel; CORREIA, Walter R. (Org.). Educação física escolar: docência e cotidiano. Curitiba: CRV, 2010. p. $109-128$.

BORGES, Cecília Maria F. O professor de educação física e a construção do saber. Campinas: Papirus, 1998. 
A formação dos docentes de educação física e seus saberes profissionais. In: BORGES, Cecília Maria F.; DESBIENS, Jean-François (Org.). Saber, formar e intervir para uma educação fisica em mudança. Campinas: Autores Associados, 2005. p. 157-190.

BOTTANI, Norberto; TUIJNMAN, Albert. The design of indicator systems. In: TUIJNMAN, Albert C.; POSTLETHWAITE, T. Neville (Ed.). Monitoring the standards of education. Oxford: Pergamon, 1994. p. 47-77.

BRACHT, Valter et al. Pesquisa em ação: educação física na escola. Ijuí: Unijuí, 2003.

BRASIL. Lei n. 4.024, de 20 de dezembro de 1961. Fixa as Diretrizes e Bases da Educação Nacional. Disponível em: <www.planalto.gov.br/ccivil_03/leis/ 14024.htm>. Acesso em: 10 mar. 2014.

. Proposta de diretrizes para a formação inicial de professores da educação básica em cursos de nível superior. Maio, 2000. Disponível em: <http:||portal.mec.gov.br| cne/arquivos/pdf/basica.pdf >. Acesso em: 15 fev. 2014.

Decreto-Lei n. 11.274, de 6 de fevereiro de 2006. Altera a redação dos artigos 29, 30, 32 e 87 da Lei n. 9.394, de 20 de dezembro de 1996, dispondo sobre a duração de 9 (nove) anos para o Ensino Fundamental. Brasília, DF: Casa Civil, 2006.

BRASIL. Instituto Nacional de Estudos e Pesquisas Educacionais Anísio Teixeira. Censo dos profissionais do magistério da educação básica 2003.

Disponível em: <http://portal.inep.gov.br/profissionais-do-magisterio>. Acesso em: 22 jan. 2014.

BRASIL. Ministério da Educação. Secretaria de Educação Fundamental. Parâmetros Curriculares Nacionais: educação física. Brasília, DF: MEC/SEF, 1997.

Referenciais para formação de professores. Brasília: SEF, 1999.

BRYK, Anthony A.; HERMANSON, Kim M. Educational Indicator Systems: Observations on their Structure, Interpretation, and Use. Review of Research in Education, [S.1], v. 19, p. 451-484, 1993.

DARIDO, Suraya Cristina. Educação Física na escola: questões e reflexões. Rio de Janeiro: Guanabara Koogan, 2003.

Os conteúdos da Educação Física na escola. In: DARIDO, Suraya Cristina; RANGEL, Irene Conceição A. (Coord.). Educação física na escola: implicações para prática pedagógica. Rio de Janeiro: Guanabara Koogan, 2005. p. 64-79.

DARLING-HAMMOND, Linda. The right to learn: a blueprint for creating schools. Jossey-Bass: New York, 1997.

DARLING-HAMMOND, Linda; ASCHER, C. Creating accountability in big city schools. Urban Diversity Series, New York, n. 102, p. 4-46, Mar. 1991.

DAY, Christopher; GU, Qing. Veteran teachers: commitment, resilience and quality retention. Teachers and Teaching: Theory and Practice, v. 15, n. 4,

p. 441-457, 2009. 
FERREIRA, Lílian Aparecida. 0 professor de educação física no primeiro ano da carreira: análise da aprendizagem profissional a partir da promoção de um programa de iniciação à docência. 2006. 229 f. Tese (Doutorado em Educação) - Universidade Federal de São Carlos, São Carlos, 2006.

GROSSMAN, Pamela; WINEBURG, Sam. What makes a teacher community different from a gathering of teachers? Research Report, Center for the Study of Teaching Policy, University of Washington, p. 1-64, Dec. 2000.

IMBERNÓN, Francisco. La profesión docente ante los desafíos del presente y del futuro. In: MARCELO GARCIA, Carlos (Ed.). La función docente. Madrid: Síntesis, 2001. p. 27-45.

KUNZ, Elenor. Transformação didático-pedagógica do esporte. Ijuí: Unijuí, 1994.

. Educação física: ensino e mudanças. 3. ed. Ijuí: Unijuí, 2004.

LAKATOS, Eva Maria; MARCONI, Marina de A. Técnicas de pesquisa. 3. ed. São Paulo: Atlas, 1996.

LEAL, Paulo Henrique. A experiência docente na educação física escolar. 2007. 117 f. Trabalho de Conclusão de Curso (Graduação) - Departamento de Educação Física, Universidade Estadual Paulista, Bauru, 2007.

. A educação física no ciclo II do ensino fundamental: refletindo sobre indicadores educacionais de desenvolvimento profissional da docência com um professor experiente. 189 p. Dissertação (Mestrado em Educação) Universidade Federal de São Carlos, São Carlos, 2011.

LEAL, Paulo Henrique; FERREIRA, Lílian Aparecida. A experiência docente na educação física escolar. In: ENCONTRO FLUMINENSE DE EDUCAÇÃO FÍSICA ESCOLAR, 10., 2006, Niterói. Anais... Niterói: Universidade Federal Fluminense, Departamento de Educação Física e Desportos, 2006. p. 38-42.

. A docência na educação física escolar: um olhar sobre a reflexão. In: ENCONTRO FLUMINENSE DE EDUCAÇÃO FÍSICA ESCOLAR, 11., 2007a, Niterói. Anais... Niterói: Universidade Federal Fluminense, Departamento de Educação Física e Desportos, 2007a. p. 19-30.

. Prática docente ao longo do tempo. In: SEMINÁRIO DE ESTUDOS E PESQUISA EM FORMAÇÃO PROFISSIONAL NA EDUCAÇÃO FÍSICA, 3., 2007b, Rio Claro. Anais... Rio Claro: NEPEF, 2007b.

. Experiência docente e avaliação na educação física escolar. In: SEMINÁRIO DE ESTUDOS E PESQUISAS EM FORMAÇÃO PROFISSIONAL NO CAMPO DA EDUCAÇÃO FÍSICA, 4., 2008, Bauru. Anais... Bauru: Universidade Estadual Paulista, 2008.

. Tempo de carreira e temporalidade na constituição da experiência docente. In: CONGRESSO SOBRE FORMAÇÃO DE PROFESSORES, 10., 2009, Águas de Lindoia. Anais... Águas de Lindoia, 2009. p. 9273-9284.

. Refletindo sobre a experiência docente na educação física escolar. In: GONÇALVES JUNIOR, Luiz; CORRÊA, Denise Aparecida; RODRIGUES, Cae (Org.). Educação e experiência: construindo saberes em diferentes contextos. Curitiba: CRV, 2011. p. 69-94. 
LUSTICK, David; SYKES, Gary. National board certification as professional development: what are teachers learning? An empirical investigation of the learning outcomes from the National Board for Professional Teaching Standards' Certification Process. [S.1.], 2006. Disponível em: $<$ www.nbpts.org/sites/default/files/documents/research/LustickSykes_ NBCasPD_WhatAreTeachersLearning.pdf>. Acesso em: 3 fev. 2006.

MINAYO, Maria Cecília de S. O desafio do conhecimento científico: pesquisa qualitativa em saúde. 2. ed. São Paulo/Rio de Janeiro: Hucitec-Abrasco, 1993.

NEW SOUTH WALES. Government. The NSW Institute of Teachers. Sydney South, 2010. Disponível em: <www.nswteachers.nsw.edu.au>. Acesso em: 7 fev. 2012.

NUTTALL, Desmond. L. Choosing Indicators. In: RILEY, Kathryn; NUTTALL, Desmond (Ed.). Measuring quality: education indicators. London: The Falmer Press, 1994.

PACHECO, José Augusto B.; FLORES, Maria Assunção. Formação e avaliação de professores. Porto: Porto, 1999.

PAPI, Silmara de O. G.; MARTINS, Pura Lúcia O. As pesquisas sobre professores iniciantes. Educação em Revista, v. 26, n. 3, p. 39-56, 2010. Disponível em: <http://dx.doi.org/10.1590/S0102-46982010000300003>. Acesso em: 3 fev. 2012.

PARANÁ. Secretaria de Estado da Educação. Diretrizes curriculares para o ensino fundamental educação física, 2006. Versão preliminar. Disponível em: <www8. pr.gov.vr/portals/portal/diretrizes/dir_ef_educfis.pdf>. Acesso em: 17 jan. 2011.

POULSON, Louise. Paradigm lost? Subject knowledge, primary teachers and education policy. British Journal of Educational Studies, v. 49, n. 1, p. 40-55, 2001.

REALI, Aline M. M. R. Indicadores educacionais, professores e a construção do sucesso escolar. Ensaio. Avaliação e Políticas Públicas em Educação, Rio de Janeiro, v. 9, n. 30, p. 79-108, 2001.

Indicadores de desenvolvimento profissional da docência: construção e avaliação. Brasília, DF: CNPQ 2011. Relatório de Pesquisa.

REALI, Aline M. M. R. et al. Qual a base de conhecimentos que meu aluno deve ter? Uma experiência de ensino e aprendizagem de construção de indicadores educacionais. Revista Brasileira de Estudos Pedagógicos, Brasília, DF, v. 85, p. 67-84, 2005.

SANCHES NETO, Luiz; BETTI, Mauro. Convergência e integração: uma proposta para a Educação Física de $5^{\mathrm{a}}$ a $8^{\mathrm{a}}$ séries. Revista Brasileira de Educação Física e Esportes, São Paulo, v. 22, n. 1, p. 5-23, jan./mar. 2008.

As dinâmicas específicas do trabalho com a educação física e a formação permanente do professorado para a docência. Palestra proferida por Luiz Sanches Neto no Núcleo de Estudos de Fenomenologia e Educação Física - NEFEF/ UFSCar, São Carlos, 2010.

SANDERS, Nancy M.; KEARNEY, Karen M. (Ed.). Performance expectations and indicators for education leaders: an ISLLC-Based guide to implementing leader standards and a companion guide to the educational leadership 
policy standards: ISLLC, 2008. Washington, DC: Council of Chief State School Officers. Disponível em: <www.ccsso.org/publications/details. cfm?PublicationID=367>. Acesso em: 3 fev. 2012.

SANTA CATARINA. Secretaria de Estado da Educação e do Desporto. Proposta curricular de Santa Catarina: educação infantil, ensino fundamental e médio: disciplinas curriculares. Florianópolis: Cogen, 1998.

SÃO PAULO (Estado). Proposta curricular de Educação Física do estado de São Paulo, 2008. Disponível em: <www.rededosaber.sp.gov.br/portais/Portals/18/ arquivos/Prop_EDF_COMP_red_md_20_03.pdf>. Acesso em: 17 jan. 2011.

SHAVELSON, Richard J.; BAXTER, Gail P.; PINE, Jerome. Performance assessment in science. Applied Measurement in Education, v. 4, n. 4, p. 347-36, 1991.

SHULMAN, Lee S. Paradigmas y programas de investigación en el estudio de la enseñanza. In: WITTROCK, Merlin C. (Org.). La investigación de la enseñanza. Barcelona: Paidós, 1989. p. 9-91.

. Conocimiento y enseñanza: fundamentos de la nueva reforma. Profesorado: Revista de Currículum y Formación del Profesorado, v. 9, n. 2, p. 1-30, 2005. Disponível em: <http://www.ugr.es/ recfpro/Rev92. html>. Acesso em: 17 jan. 2011.

VILLEGAS-REIMERS, Eleonora. Teacher professional development: an international review of literature. Paris: Unesco/ International Institute for Educational Planning, 2003.

\section{PAULO HENRIQUE LEAL}

Doutorando no Programa de Pós-Graduação em Educação da Universidade Federal de São Carlos (UFSCar), São Carlos, São Paulo, Brasil. Professor no Centro Universitário da Fundação Educacional de Barretos (Unifeb), Barretos, São Paulo, Brasil paulinho_bauru@hotmail.com

\section{ALINE MARIA DE MEDEIROS RODRIGUES REALI}

Professora do Programa de Pós-Graduação em Educação da Universidade Federal de São Carlos (UFSCar), São Carlos, São Paulo, Brasil

alinereali@ufscar.br 
